\title{
Antara Ada dan Tiada: Studi Terhadap Tingkat Kehadiran dan Keaktifan Mahasiswa dalam Pembelajaran Online di Era Covid-19
}

\author{
Soni Ariawan \\ soniariawan@uinmataram.ac.id \\ Prograrm Studi Tadris Bahasa Inggris, Fakultas Tarbiyah dan Keguruan, \\ Universitas Islam Negeri Mataram, Indonesia

\begin{abstract}
Exist, or not: A Case Study on Student Attendance and Activeness in Online Learning During the Covid-19 Era
\end{abstract}

\begin{abstract}
The study aims to analyze the level of students' attendance and interaction as well the availability of internet access during online learning in the era of Covid-19 pandemic. The case study is conducted at the English Language Education Study Program, Faculty of Education and Teacher Training State Islamic University of Mataram. This research is a part of quantitative research design with surveys. The researcher developed a set of questionnaire in Google Form and shared it to the students via WhatsApp group. 215 students participated in this study. It was found that most of the students attended the class throughout the meetings, but it could not be concluded that they participated during the class from the beginning till the end of the meeting. The causes were by the lack of internet access, instability of signal as well as the availability of the devices. The phenomenon showed that students exist in the class but do not exist. A successful learning occurs when interaction and communication run smoothly among students and teachers.
\end{abstract}

Keywords: Exist But Not Exist, Interaction, Activeness, Internet Access, Online Learning In Covid-19 Era

\section{PENDAHULUAN}

Salah satu sektor yang sangat terdampak dengan pandemi Covid-19 adalah sektor pendidikan. Berdasarkan data dari UNESCO per 14 April 2020, 192 negara menutup institusi pendidikan skala nasional dan lokal yang berdampak pada hampir 1,6 miliar siswa atau 91,4\% dari total siswa di negaranegara tersebut, termasuk Indonesia (UNESCO, 2020). Sekitar 28,6 juta siswa di Indonesia dari jenjang Sekolah Dasar sampai Sekolah Menengah di sejumlah provinsi harus berpindah dari pembelajaran di kelas ke pembelajaran dalam jaringan (daring).

Bukan hanya sekolah, Perguruan Tinggi Negeri dan Swasta juga tidak luput dari dampak pandemi ini. Mahasiswa harus mengikuti pembelajaran jarak jauh dengan berbagai dinamika perkuliahan. Penugasan, diskusi, ujian, sidang skripsi dan semua kegiatan akademik dilaksanakan dengan online. Kondisi pandemi ini menimbulkan semacam "efek kejut" dalam dunia pendidikan. Kita tidak pernah dihadapkan dengan kondisi seperti ini sebelumnya. Design pelaksanaan kegiatan belajar mengajar serta berbagai komponen kurikulum di dalamnya juga hanya didesign dalam konteks tatap muka (face-to-face), tidak terintegrasi dengan pembelajaran online. Menjadi sebuah hal yang wajar kemudian jika terjadi berbagai bentuk kekurangan baik dari segi kesiapan kurikulum, sumber daya serta sarana dan prasarana. Berbagai bentuk kekurangan dalam pelaksanakan pembelajaran online ini harus dievaluasi dengan baik. Hasil evaluasi ini bisa dirumuskan untuk menjadi sebuah catatan konstruktif dalam pengembangan kurikulum pendidikan yang mampu mengintegrasikan teknologi dalam pembelajaran, tidak hanya pada konteks tatap muka (face-to-face learning) tetapi juga dalam konteks pembelajaran online (online learning).

Mendiskusikan kompleksitas permasalah pendidikan di Indonesia bisa dilihat dari data tahun 2017 tentang Human Development yang merilis sebuah laporan tentang Education Index dimana Indonesia menempati urutan ke 7 di ASEAN dengan skor 0,622 (Human Development, 2017). Posisi 
ini jauh tertinggal oleh Singapura dengan perolehan skor 0,832 sebagai peringkat pertama di ASEAN dan Malaysia dengan 0,719 di posisi ke dua. Perangkingan ini dihitung berdasarkan rata-rata lama sekolah dan target capaian lama sekolah yang sudah dibuat oleh Kementrian Pendidikan di negara masingmasing. Semakin tinggi angka rata-rata lama sekolah maka semakin tinggi jenjang pendidikan yang ditempuh dan begitu sebaliknya. Singapura dan Malaysia sebagai peringkat pertama dan ke dua di ASEAN memilik rata-rata lama sekolah 11,5 tahun dan 10,2 tahun. Sementara itu, ratarata lama sekolah di Indonesia hanya 8 tahun. DKI Jakarta menempati peringkat tertinggi dengan rata-rata 11,06 tahun, sementara itu Gorontalo, NTT, NTB, Kalimantan Barat dan Papau termasuk dalam provinsi dengan peringkar rerata lama sekolah rendah yaitu di bawah 8 tahun.

Pada tahun 2019 lalu, peringkat kualitas pendidikan di Indonesia dinilai merosot dalam evaluasi Programme for International Student Assessment (PISA). Peringkat Indonesia menurun hampir di semua indikator penilaian seperti membaca, matematika dan sains terhitung sejak mengikuti PISA tahun 2000. Kesimpulan dari perangkingan yang dirilis oleh OECD (Organization for Economic Cooperation and Development) ini adalah hanya $30 \%$ siswa Indonesia yang memenuhi kompetensi membaca minimal, kurang dari 40\% mencapai kompetensi minimal di Matematika dan 40\% siswa masih berada di bawah kemampuan minimal yang diharapkan dalam bidang sains. Hal ini menunjukkan bahwa kompleksitas permasalah pendidikan di Indonesia tidak hanya meliputi sarana dan prasarana dan kualitas lulusan, tetapi juga pada sumber daya dimana masih banyak guru yang belum memiliki kompetensi minimal dalam melaksanakan pembelajaran yang berkualitas. Pembelajaran online di tengah pandemi ini juga menambah daftar masalah yang muncul. Beberapa aspek yang paling disoroti adalah akses terhadap internet, ketersediaan sarana dan prasarana serta literasi digital.

Tidak semua siswa mampu membeli smart phone atau laptop untuk mengikuti kelas dan mengerjakan tugas-tugas. Siswa yang berasal dari keluarga dengan penghasilan rendah tentu tidak akan memprioritaskan membeli smart phone sebelum kebutuhan dasarnya terpenuhi. Hasil riset Asosiasi Penyelenggara Jasa Internet Indonesia (APJII) tahun 2018 memang menunjukkan bahwa penetrasi penguna internet dalam bidang pendidikan terbilang cukup tinggi (Asosiasi Penyelenggara Jasa Internet Indonesia, 2018). Tujuh dari sepuluh siswa dan $92 \%$ mahasiswa menggunakan internet. Tetapi data ini belum menggambarkan persebarannnya. Jika dilihat lebih rinci dari data pengguna internet tersebut, lebih dari setengah berada di wilayah Jawa $(55,7 \%)$, diikuti wilayah Sumatera $(21,6 \%), 10,9 \%$ di kawasan Sulawesi-Maluku-Papua, Kalimantan $(6,6 \%)$ dan Bali Nusa Tenggara (5,2\%). Persebaran sarana dan prasarana serta jaringan internet masih belum merata.

Literasi digital berkaitan dengan erta kompetensi guru dan siswa dalam mengakses informasi dan menggunakan teknologi untuk mendiskusikan materi, berinteraksi dan membangun keaktifan (engagement), mengerjakan tugas dan melakukan evaluasi belajar dan pembelajaran. Literasi teknologi sangat diperlukan pada saat sekarang ini dengan kondisi yang tidak memungkinkan untuk belajar di kelas. Urgensi kompetensi digital ini bukan hanya karena kondisi pembelajaran yang harus dilaksanakan dengan online, tetapi juga karena penyebaran informasi yang begitu luas dan cepat membuat guru harus beradaptasi karena hal ini rentan dengan penyalahgunaan informasi dan ketidakmampuan individu dalam menyaring informasi dalam mengkonsumsi produk media digital, terlebih lagi menganalisis sejauh mana informasi tersebut bermanfaat (Asari et al., 2019). Penelitian ini bertujuan untuk menganalisi tingkat kehadiran mahasiswa dalam pembelajaran online serta menginvestigasi tingkat aksesibilitas mereka terhadap internet dalam kontek pembelajaran di perguruan tinggi.

\section{KAJIAN PUSTAKA}

Berbagai studi yang lebih detail juga telah dilakukan terkait dengan kekurangan pembelajaran online dan pengalaman siswa mengikuti pembelajaran online. Seperti penelitian yang dilakukan oleh Handayani (2020), dia menemukan bahwa ada tiga hal yang sering dikeluhkan oleh siswa saat pembelajaran online, yaitu ketidakstabilan jaringan yang mengakibatkan ketidakjelasan suara guru, bahan ajar atau material tidak didapatkan secara merata bahkan ada yang tidak bisa mengakses sama sekali. Kondisi lain yang sering dikeluhkan adalah terjadinya interaksi sepihak oleh guru atau guru dengan siswa yang aktif saja. Kondisi ini sangat berbeda dengan pembelajaran tatap muka dimana guru seringkali interaktif dalam menjelaskan materi. Selain dua hal sebelumnya, kesulitan siswa dalam berkonsentrasi juga menjadi hal yang dikeluhkan. Siswa mengaku cepat terganggu oleh faktor teknis 
dan lingkungan sehingga tidak bisa mengikuti pembelajaran secara efektif. Minimnya prasarana dan faktor ketidakmampuan untuk mengakses internet karena faktor ekonomi serta ketidaksiapan teknologi juga menjadi suatu hambatan dalam berlangsungnya kegiatan belajar online. Hasilnya kemudian sudah bisa ditebak bahwa pembelajaran tidak akan 100\% lancar dan efektif (Dwi et al., 2020).

Fakta di lapangan menunjukkan bahwa masih ada guru yang tidak mampu mengoperasikan dan mengaplikasikan teknologi di kelas virtual (virtual classroom) selama pandemik. Akibatnya pembelajaran hanya dilakukan dengan memberikan berbagai tugas tanpa interaksi dan komunikasi. Pembelajaran seperti ini tidak akan membuahkan hasil maksimal, melainkan siswa akan terbebani. Data menunjukan bahwa pelaksanaan pembelajaran daring (online) hanya sebatas di grup WhatsApp (WAG), tanpa memaksimalkan platform lain yang lebih interaktif dan akomodatif seperti zoom, google meet atau google classroom (Kholid, 2020).

Kemampuan finansial juga menjadi masalah yang dihadapi oleh para siswa. Mereka harus membeli kuota yang cukup agar tidak ketinggalan semua pelajaran. Pasalnya, selain berbasis handphone, ada juga guru yang mengharuskan siswa untuk menggunakan video yang pastinya membutuhkan kuota internet lebih banyak. Kondisi ini tentu tidak bisa dipaksakan kepada siswa yang berasal dari keluarga berpenghasilan menengah ke bawah. Banyak di antara siswa yang tidak mampu membeli handphone, apalagi internet untuk mengikuti pembelajaran online, terlebih lagi bahwa aktivitas pembelajaran mereka tidak bisa dikontrol secara langsung sebagaimana kelas tatap muka (Atsani, 2020). Ketidakmampuan mereka membeli paket data internet, kondisi jaringan yang tidak stabil serta permasalahan teknis lainnya justru menjadi faktor penyebab kecemasan siswa dalam belajar sehingga pembelajaran menjadi tidak efekftif (Oktawirawan, 2020). Belum lagi faktor yang datang dari orang tua dimana tidak sedikit orang tua yang mengeluh dan merasa terganggu dengan pembelajaran online. Dalam penelitian terkini tentang studi eksploratif dampak pandemik Covid-19 terhadap proses pembelajaran online pada sekolah dasar di Jakarta menemukan bahwa salah satu kekurangan dalam pembelajaran online, yaitu orang tua merasa terbebani (Purwanto et al., 2020). Mereka harus mendampingi anak dalam mengikuti pembelajaran. Mereka memprotes beberapa guru yang hanya memberikan tugas kepada siswa tanpa diikuti dengan instruksi yang jelas.

Deretan kendala ini tentu tidak hanya dialami oleh siswa di sekolah, tetapi juga oleh mahasiswa di perguruan tinggi. Kendala tersebut akan sangat berpengaruh terhadap kehadiran dan keaktifan siswa dalam belajar. Tingkat keaktifan harusnya bisa diukur dari bagaimana mereka mampu menyelesaikan masalah atau tugas, aktif dan berinteraksi dengan guru dan temannya dan melakukan berbagai kegiatan lainnya (Nurhayati, 2020). Bahkan Setiawan \& Maring (2020) membuat sebuah kreativitas dengan mengharuskan siswanya untuk berfoto selfie dan dikirim di grup WhatsApp. Hal ini dilakukan untuk memastikan kahadiran dan keaktifan siswa. Ini adalah salah satu pengaruh dari pembelajaran online dimana motivasi siswa berkurang. Di sisi lain, ketidakhadiran dan ketidakaktifan siswa, selain karena faktor teknis, dikarenakan minimnya pengawasan dan dorongan dari orang tua untuk mengerjakan tugas dan mengikuti pembelajaran. Tidak semua orang tua mampu menghadirkan suasana belajar yang nyaman di rumah (Kurnia, 2021).

Di sisi lain, pembelajaran online tentu tidak sepenuhnya bermuatan negatif, beberapa penelitian juga menunjukkan bahwa siswa cukup aktif dalam mengerjakan aktivitas seperti download materi, mengerjakan kuis, latihan soal dan mengikuti diskusi (Ratnasari, 2012). Khususnya jika media pembelajaran yang digunakan cukup interaktif dengan mengkombinasikan audio dan video seperti zoom, google meet dll. Pembelajaran melalui video di tengah pandemi cenderung lebih efektif dibandingkan pembelajaran dengan zoom dan platform lainnya karena selain alasan efektivitas, siswa merasa mandiri dan mudah mengakses video di Youtube dibandingkan harus menyiapkan paket data yang cukup untuk mengikuti kelas di zoom, google meet atau platform video conference lainnya. Penelitian yang lain juga mengkonfirmasi efektifitas pembelajaran secara online dengan media yang bervariasi dapat meningkatkan keaktifan siswa karena mereka mengakut bahwa belajar secara online dengan berbagai media pendukung seperti video dan variasi media pembelajaran lain tidak monoton. Ketertarikan ini menimbulkan semangat belajar yang tinggi sehingga mereka berperan aktif dalam pembelajaran (Paseleng \& Sanoto, 2021). Dengan kekatifan ini, siswa akan dengan memudah untuk termotivasi dalam membangun dan mengembangkan pengetahuannya sebagai subjek dalam pembelajaran (Prijanto \& Kock, 2021).

Banyak penelitian yang telah membuktikan efektivitas pembelajaran dengan video dan kaitannya dengan peningkatan prestasi belajar siswa dan menunjukkan korelasi yang positif dimana 
siswa di kelas eksperimen lebih baik prestasi belajarnya dibandingkan siswa di kelas kontrol (Rahayu \& Amri, 2021). Hal ini menjelaskan bahwa hasil penelitian sangat tergantung dari lokasi penelitian yang bisa jadi ketersediaan dan keterjangkauan akses internet dan sarana serta prasarana juga berbeda. Faktor ini tentu akan memengaruhi respon dan persepsi responden.

\section{METODE PENELITIAN}

Penelitian ini merupakan penelitian dengan desain kuantitatif-deskriptif dengan metode survei. Data dalam penelitian ini diperoleh dengan menggunakan kuesioner yang disebarkan melalui grup WhatsApp (WAG). Ada dua pertanyaan besar yang diajukan di dalam kuesioner, yaitu terkait dengan tingkat kekatifan siswa dan tingkat keaktifan dalam mengakses internet. Responden penelitian merupakan mahasiswa Program Studi Tadris Bahasa Inggris Universitas Islam Negeri Mataram dimana kegiatan pembelajaran di Universitas Islam Negeri Mataram menggunakan LMS Moodle yang dikombinasikan dengan Google Meet atau Zoom sebagaimana instruksi dari universitas. Penggunaan kuesioner dalam penelitian ini sangat relevan sebagai sebuah teknik pengumpulan data dengan membuat daftar pertanyaan atau pernyataan sesuai dengan variabel yang akan diukur, dianalisis dan diharapkan, yang disajikan secara online atau tertulis (Sugiyono, 2019).

Seperangkat pertanyaan dan pernyataan dalam penelitian ini dibuat dengan menggunakan google form yang disajikan dalam intem pilihan ganda (multiple choice items). Sebanyak 215 mahasiswa yang terdiri dari 78 laki-laki dan 37 perempuan, berpartisipasi dalam penelitian ini. Data kemudian dianalisis secara kuantitatif dengan menghitung jumlah responden yang memilih jawabanatau opsi tertentu. Peneliti kemudian melakukan analisis terhadap frekuensi dan persentase masing-masing pilihan responden pada setiap item pertanyaan. Hasil dari analisis ini ditampilkan dalam bentuk tabel, kemudian dilakukan deskripsi dan interpretasi terhadap hasil analisis tersebut untuk menjelaskan dua variabel utama, yaitu tingkat kehadiran mahasiswa selama perkuliahan online dan akses internet selama pembelajaran online.

\section{HASIL PENELITIAN DAN PEMBAHASAN}

Dalam hasil penelitian ini ditemukan bahwa secara umum, tingkat kehadiran mahasiswa lebih dari $90 \%$. Kehadiran yang dimaksud dalam item ini adalah kehadiran secara umum tanpa melihat apakah mahasiswa tersebut hadir dari awal sampai akhir perkuliahan atau hanya mengisi daftar hadir secara online dan setelah itu tidak aktif atau tidak ikut perkuliahan. Pada item pertanyaan ke 2, terbukti bahwa lebih dari 20\% mahasiswa hanya menghadiri 61-80 persen perkuliahan selama pembelajaran online, bahkan $12 \%$ dari mereka hanya menghadiri 50 persen total pertemuan selama perkuliahan tersebut, padahal batas toleransi ketidakhadiran adalah 20 persen.

Hal menarik lain dalam penelitian ini adalah persentase keaktifan dan interaksi siswa. Ditemukan bahwa hanya 20\% dari total responden yang 80-100 persen aktif berinteraksi selama pembelajaran online. Sisanya hanya aktif maksimal sampai 80 persen, bahkan hampir $30 \%$ dari mereka hanya memiliki 40 persen tingkat keaktifan dan interaksi selama pembelajaran online. Dari sisi interaksi dan keaktifan ini, bisa disimpulkan bahwa masih ada sebagian mahasiswa yang kesuitan dalam melakukan interaksi dan aktif selama proses pembelajaran online. Hasil penelitian ini berbeda dengan penelitian Ratnasari (2012).

Tabel 1. Tingkat Kehadiran Siswa

\begin{tabular}{lcc}
\hline Indikator & Frekuensi & Persentase \\
\hline 1). Selama online learning, saya menghadiri kelas & & \\
\hline$Y a$ & 109 & $94.8 \%$ \\
\hline Tidak & 6 & $5.2 \%$ \\
\hline 2). Rate kehadiran selama online learning & \\
\hline $0-20 \%$ & 2 & $1.7 \%$ \\
\hline $21-40 \%$ & 3 & $2.6 \%$ \\
\hline $41-60 \%$ & 11 & $9.6 \%$ \\
\hline $61-80 \%$ & 26 & $22.6 \%$ \\
\hline $81-100 \%$ & 73 & $63.5 \%$ \\
\hline 3$).$ Selama online learning, saya aktif berinterkasi di kelas & & \\
\hline$Y a$ & 101 & $87.8 \%$ \\
\hline
\end{tabular}


Antara Ada dan Tiada: Studi Terhadap Tingkat Kehadiran dan Keaktifan Mahasiswa dalam

Pembelajaran Online (Soni Ariawan)

\begin{tabular}{ccc}
\hline Tidak & 14 & $12.2 \%$ \\
\hline 4). Rate keaktifan berinteraksi di kelas online & & \\
\hline $0-20 \%$ & 2 & $1.7 \%$ \\
\hline $21-40 \%$ & 6 & $5.2 \%$ \\
\hline $41-60 \%$ & 26 & $22.6 \%$ \\
\hline $61-80 \%$ & 57 & $49.6 \%$ \\
\hline $81-100 \%$ & 24 & $20.9 \%$ \\
\hline
\end{tabular}

Selain tingkat kehadiran dan keaktifan, penelitian ini juga menginvestigasi bagaimana mahasiswa mengakses internet dan ketersediaan perangkat pendukung dalam pembelajaran online. Lebih dari $80 \%$ mahasiswa memiliki akses terhadap internet. Akses yang dimaksud di sini adalah ketersediaan paket data atau wifi secara umum, tanpa melihat tingkat kestabilan sinyal maupun ganguan teknis lainnya. Sebagian besar dari mahasiswa menggunakan handphone atau smartphone sebagai perangkat dalam mengakses materi dan mengikuti pembelajaran. Tingkat kekatifan yang signifikan dalam pembelajaran online memang dialami oleh sebagian siswa sebagaimana hasil penelitian sebelumnya bahwa mereka tertarik dengan variasi media pembelajaran yang digunakan oleh guru (Paseleng \& Sanoto, 2021; Prijanto \& Kock, 2021; Ratnasari, 2012).

Salah satu poin yang menarik dalam hasil penelitian ini adalah jawaban responden terhadap pertanyaan yang mengkonfirmasi kekuatan sinyal. Lebih dari $60 \%$ dari mereka menjawab sinyal tidak stabil, bahkan cenderung lemah. Angka 60\% ini merupakan jumlah yang tidak sedikit. Mayoritas dari mereka mengalami kendala sinyal dalam mengikuti pembelajaran online. Faktor ini sangat berpotensi menjadi faktor penyebab kenapa tingkat keaktifan dan interaksi mahasiswa sangat rendah. Hasil penelitian dalam hal akses internet ini sama dengan penelitian yang dilakukan oleh Handayani (2020) dan Oktawirawan (2020) yang menemukan bahwa tidak tersedianya sinyal internet menjadi salah satu faktor yang dikeluhkan oleh siswa dalam pembelajaran online. Bahkan Oktawirawan (2020) menyebutkan hal ini menjadi salah satu faktor yang menyebabkan kecemasan siswa dalam belajar.

Tabel 2. Akses Internet

\begin{tabular}{|c|c|c|}
\hline Indikator & Frekuensi & Persentase \\
\hline \multicolumn{3}{|c|}{ 1). Akses internet di rumah } \\
\hline Tersedia & 88 & $76.5 \%$ \\
\hline Tidak tersedia & 27 & $23.5 \%$ \\
\hline \multicolumn{3}{|l|}{ 2). Kekuatan sinyal } \\
\hline Stabil & 48 & $41.7 \%$ \\
\hline Tidak stabil & 54 & $47 \%$ \\
\hline Sangat lemah & 13 & $11.3 \%$ \\
\hline \multicolumn{3}{|c|}{ 3). Ketersedian paket data/wifi } \\
\hline Cukup & 54 & $56.5 \%$ \\
\hline Tidak cukup & 50 & $43.5 \%$ \\
\hline \multicolumn{3}{|c|}{ 4). Perangkat yang digunakan } \\
\hline Smartphone & 110 & $95.7 \%$ \\
\hline Laptop & 5 & $4.3 \%$ \\
\hline \multicolumn{3}{|l|}{ 5). Kecocokan perangkat } \\
\hline Cocok & 89 & $77.4 \%$ \\
\hline Tidak cocok & 26 & $22.6 \%$ \\
\hline
\end{tabular}

Secara ringkas, dalam penelitian ini ditemukan bahwa mahasiswa secara umum ada (menghadiri kelas). Namun, keberadaannya tidak bisa dipastikan akan berlangsung lama, sampai pembelajaran selesai atau hanya setengah sesi dan setelah itu tidak aktif kembali (tiada). Bahkan, ada yang lebih lucu dalam pembelajaran online, dimana mahasiswa hadir (ada) dalam ruang zoom, google meet atau terdeteksi ikut membaca materi lewat grup WhatsApp, tetapi mereka tidak ada respon sama sekali (tiada), cenderung diam dan membisu. Dalam kondisi seperti ini, tercipta ruang persepsi di benak guru dan dosen bahwa mereka (mahasiswa) antara mengerti dan tidak mengerti, khusuk menyimak, terjadi permasalahan teknis dengan audio, video atau sinyal atau ada kesibukan lain yang lebih penting sehingga diwakili oleh akunnya untuk mengikuti pembelajaran. 
Hasil dalam penelitian ini mengkonfirmasi penelitian yang dilakukan oleh Setiawan \& Maring (2020) tentang minimnya tingkat kehadiran siswa . Dalam penelitian ini, ditemukan bahwa mahasiswa ada (mengisi daftar hadir), tetapi kadang menjadi tidak aktif atau bahkan keluar dari ruang virtual (tiada) beberapa saat kemudian. Kendala sinyal, kuota internet dan kendala teknis lainnya tentu terjadi bukan hanya pada mahasiswa, tetapi juga dosen. Dalam konteks ini, mahasiswa dan dosen harus saling memaklumi. Kondisi seperti ini cenderung membuat para pengajar harus semakin bersabar tetapi tetap mengasah kreativitas pedagogi, bagaimana agar siswa tertarik mengikuti pembelajaran, misalnya melalui game (Nurhayati, 2020), aplikasi yang menarik (Mulyana et al., 2020), media sosial seperti instagram (Veygid et al., 2020), game Kahoot (Hartanti, 2019) atau Edmodo (Putranti, 2016).

\section{SIMPULAN DAN SARAN}

Kondisi faktual di suatu sekolah atau perguruan tinggi bisa saja berbeda dengan kondisi di sekolah atau perguruan tinggi lain. Akses terhadap internet dan ketersediaan sarana dan prasarana bisa saja berbeda. Ada banyak faktor yang memengaruhi hal ini. Berbagai penelitian telah mengeksplorasi bahwa efektifitas pembelajaran online sangat dipengaruhi oleh faktor-faktor di atas, selain faktor internal yang berkaitan dengan skill dan kompetensi tenaga pengajar. Dalam penelitian ini, ditemukan bahwa secara umum mahasiswa menghadiri sebagian besar sesi dalam pembelajaran online, tetapi sebagian dari mereka pasif atau tidak melakukan interaksi yang aktif, baik dengan dosen maupun sesama mahasiswa. Penyebabnya bisa karena mahasiswa tidak memiliki akses internet yang memadai atau adanya faktor internal yang membuat mereka malas untuk menghadiri kelas. Penelitian ini berperan penting dalam menyajikan potret faktual bagaimana tingkat kekatifan siswa serta aksesibilitas mereka terhadap internet. Hal ini sangat bermanfaat dalam memetakan atau menentukan media pembelajaran yang tepat sehingga tidak hanya efektif dalam mencapai tujuan belajar, tetapi juuga dapat digunakan dan dijangkau oleh mahasiswa. Penelitian lebih lanjut terkait hal ini perlu dilakukan dalam dalam skala yang lebih luas dengan lintas program studi atau bahkan perguruan tinggi dalam rangka mendapatkan data yang lebih valid dan detail terkait faktor internal dan eksternal yang menentukan tingkat keaktifan mahasiswa dalam pembelajaran online selama pandemi Covid-19.

\section{DAFTAR PUSTAKA}

Asari, A., Kurniawan, T., Ansor, S., \& Putra, A. B. N. R. (2019). Kompetensi Literasi Digital Guru dan pelajar di Lingkungan Sekolah Kabupaten Malang. BIBLIOTIKA : Jurnal Kajian Perpustakaan dan Informasi, 3(2), 98-104.

Asosiasi Penyelenggara Jasa Internet Indonesia. (2018). Penetrasi Internet di Indonesia. https://apjii.or.id/content/read/104/348/BULETIN-APJII-EDISI-22---Maret-2018

Atsani, K. L. G. M. Z. (2020). Transformasi Media Pembelajaran pada Masa Pandemi Covid-19`. alHikmah: Jurnal Studi Islam, 1(1), 82-93.

Dwi, C. B., Amelia, A., Hasanah, U., Putra, A. M., \& Rahman, H. (2020). Analisis Keefektifan Pembelajaran Online di Masa Pandemi Covid-19. MAHAGURU: Jurnal Pendidikan Guru Sekolah Dasar, 2(1), 28-37.

Handayani, L. (2020). Keuntungan, Kendala dan Solusi Pembelajaran Online Selama Pandemi Covid19: Studi Ekploratif di SMPN 3 Bae Kudus. Journal of Industrial Engineering \& Management Research, 1(2), 15-23. https://doi.org/10.7777/jiemar.v1i2.36

Hartanti, D. (2019). Meningkatkan Motivasi Belajar Siswa dengn Media Pembelajaran Interaktif Game Kahoot Berbasis Hypermedia. 8.

Human Development. (2017). Human development Report. http://hdr.undp.org/en/indicators/103706

Kholid, K. (2020). Pentingnya Literasi Digital bagi Guru pada Lembaga Pendidikan Tingkat Dasar dan Implikasinya terhadap Penyelenggaraan Kegiatan Belajar Mengajar. Jurnal Horizon Pedagogia, 1(1), Article 1. https://jurnal.untirta.ac.id/index.php/jhp/article/view/10422

Kurnia, D. (2021). Dinamika Gejala Kejenuhan Belajar Siswa pada Proses Belajar Online dan Faktorfaktor yang Melatarbelakangi dan Implikasinya pada Layanan Bimbingan Keluarga. 
Antara Ada dan Tiada: Studi Terhadap Tingkat Kehadiran dan Keaktifan Mahasiswa dalam

Pembelajaran Online (Soni Ariawan)

TEACHING: Jurnal Inovasi Keguruan Dan Ilmu Pendidikan, 1(1), 1-10. https://doi.org/10.51878/teaching.v1i1.70

Mulyana, M., Rainanto, B. H., Astrini, D., \& Puspitasari, R. (2020). Persepsi Mahasiswa Atas Penggunaan Aplikasi Perkuliahan Daring Saat Wabah Covid-19. JAS-PT (Jurnal Analisis Sistem Pendidikan Tinggi Indonesia), 4(1), 47-56. https://doi.org/10.36339/jaspt.v4i1.301

Nurhayati, E. (2020). Meningkatkan Keaktifan Siswa Dalam Pembelajaran Daring Melalui Media Game Edukasi Quiziz pada Masa Pencegahan Penyebaran Covid-19. Jurnal Paedagogy, 7(3), 145-150. https://doi.org/10.33394/jp.v7i3.2645

Oktawirawan, D. H. (2020). Faktor Pemicu Kecemasan Siswa dalam Melakukan Pembelajaran Daring di Masa Pandemi Covid-19. Jurnal Ilmiah Universitas Batanghari Jambi, 20(2), 541-544. https://doi.org/10.33087/jiubj.v20i2.932

Paseleng, M. C., \& Sanoto, H. (2021). Implementasi Pembelajaran Online di Era Pandemi Covid-19: Tantangan dan Peluang. Scholaria: Jurnal Pendidikan Dan Kebudayaan, 11(3), 283-288.

Prijanto, J. H., \& Kock, F. de. (2021). Peran Guru Dalam Upaya Meningkatkan Keaktifan Siswa Dengan Menerapkan Metode Tanya Jawab Pada Pembelajaran Online. Scholaria: Jurnal Pendidikan Dan Kebudayaan, 11(3), 238-251.

Purwanto, A., Pramono, R., Asbari, M., Santoso, P., Chi Hyun, C., Wijayanti, L., \& Putri, R. (2020). Studi Eksploratif Dampak Pandemi COVID-19 Terhadap Proses Pembelajaran Online di Sekolah Dasar. 2, 1-12.

Putranti, N. (2016). Cara Membuat Media Pembelajaran Online Menggunakan Edmodo. Jurnal Pendidikan Informatika Dan Sains, 2(2), 139-147. https://doi.org/10.31571/saintek.v2i2.224

Rahayu, S., \& Amri, F. (2021). Perbandingan Pembelajaran Daring dengan Video dan Zoom Terhadap Hasil Belajar Siswa Pada Mata Pelajaran Ekonomi. Jurnal Simki Pedagogia, 4(1), 33-46.

Ratnasari, A. (2012). Studi Pengaruh Penerapan e-Learning terhadap Keaktifan Mahasiswa dalam Kegiatan Belajar Mengajar: Studi Kasus Universitas Mercu Buana Jakarta. Seminar Nasional $\begin{array}{llllll}\text { Aplikasi Teknologi Informasi (SNATI), } & 0, & \text { Article } & \end{array}$ https://journal.uii.ac.id/Snati/article/view/2930

Setiawan, R., \& Maring, P. (2020). Motif Berfoto Selfie untuk Presensi Kehadiran Kelas Online Saat Pandemi Covid-19 di Kalangan Pelajar Sekolah Dasar. Jurnal Pewarta Indonesia, 2(2), 90-96. https://doi.org/10.25008/jpi.v2i2.38

Sugiyono. (2019). Metode Penelitian Pendidikan (Kuantitatif, Kualitatif, Kombinasi, T\&D dan Penelitian Pendidikan). Alfabeta.

UNESCO. (2020). Education: From disruption to recovery. UNESCO. https://en.unesco.org/covid19/educationresponse

Veygid, A., Aziz, S. M., \& S.r, W. S. (2020). Analisis Fitur dalam Aplikasi Instagram sebagai Media Pembelajaran Online Mata Pelajaran Biologi untuk Siswa Sekolah Menengah Atas. ALVEOLI: Jurnal Pendidikan Biologi, 1(1), 39-48. https://doi.org/10.35719/alveoli.v1i1.5 